\title{
Enhanced VEGF Expression in Hair Follicle Dermal Papilla Cells by Centella asiatica Linn.
}

\author{
Pahol Saansoomchai ${ }^{1}$, Apinun Limmongkon ${ }^{1}$, Damratsamon Surangkul', \\ Teera Chewonarin ${ }^{2}$ and Metawee Srikummool ${ }^{1 *}$
}

\author{
${ }^{1}$ Department of Biochemistry, Faculty of Medical Science, Naresuan University, Phitsanulok \\ 65000, Thailand \\ ${ }^{2}$ Department of Biochemistry, Faculty of Medicine, Chiang Mai University, Chiang Mai \\ 50200, Thailand \\ *Corresponding author.E-mail: metaweesr@nu.ac.th \\ https://doi.org/10.12982/CMUJNS.2018.0003
}

\begin{abstract}
Centella asiatica Linn. (C. asiatica) extract has been shown to possess high antioxidant activity due to its phenols and flavonoids. This study tested the efficacy of 70\%-ethanol (EtOH) crude extracts of $\mathrm{C}$. asiatica and its fractions $\left(\mathrm{H}_{2} \mathrm{O}, \mathrm{EtOAc}, \mathrm{CH}_{2} \mathrm{Cl}_{2}\right.$, and hexane) to modulate human follicle dermal papilla cells. In addition, we analyzed the extracts for major phytochemicals as well as free radical scavenging activity. Our results from ABTS and DPPH assays showed that the amounts of phenolic and flavonoid compounds in the extracts were both related to its free radical scavenging activity. While the EtOAc fraction of C. asiatica demonstrated the highest free radical scavenging activity, it was toxic to human follicle dermal papilla cells. The cell viability test was positive when cells were treated with EtOH crude extract and $\mathrm{H}_{2} \mathrm{O}$ fraction. $\mathrm{VEGF}$ gene expression, quantified by real-time PCR analysis of the EtOH crude extract, showed a significant level of induction, indicating that the growth promotion effect in human follicle dermal papilla cells was related to VEGF gene expression, which has a positive hair growth stimulating effect. The EtOH crude extract of $C$. asiatica may offer potential in hair growth promoting products.
\end{abstract}

Keywords: Antioxidant activities, Centella asiatica, Phytochemical screening, Real-time PCR, Gene expression

\section{INTRODUCTION}

Hair protects the scalp from the environment, including heat, cold, and UV radiation, and serves as a measure of beauty. As its loss can result in distress and psychological problems, prevention or treatment strategies need to be investigated. So far, only two drugs, minoxidil and finasteride, have been approved for the treatment of hair loss in men by the US Food and Drug Administration (Park et al., 2012).

Hair follicles of any hair type have a unique life cycle comprised of three main stages anagen, catagen, and telogen, each of which leads to the destruction and regeneration of hair follicles over a lifetime. The regulation of the hair cycle is complicated and involves several 
factors (Hibino and Nishiyama, 2004) that are not well understood. Genetic factors, cytokine imbalance, and oxidative stress can cause abnormal hair follicle cycling and subsequent hair loss (Rho et al., 2005; Aron et al., 2013). Many cytokines and receptors are involved in the cell cycle of human follicle dermal papilla cells, including the vascular endothelial cell growth factor (VEGF) (Shin et al., 2014), vascular endothelial cell growth factor receptor (VEGFR) (Li et al., 2012), fibroblast growth factor (FGF) (Rho et al., 2005), insulin-like growth factor (IGF) (Panchaprateep and Asawanonda, 2014), epidermal growth factor (EGF) (Bressan et al., 2014), keratinocyte growth factor (KGF) (Gopu et al., 2015), and transforming growth factor (TGF) (Kang et al., 2013; Shin et al., 2014). Some hair regeneration has been achieved by molecular effect and growth factors (Danilenko et al., 1996) and follicle dermal stem cells (Rahmani et al., 2014). Some evidence has suggested that VEGF and VEGFR could induce the proliferation of human follicle dermal papilla cells through ERK activation (Li et al., 2012). TGF has been related to human follicle dermal papilla cell death involving free radicals (Soma et al., 2003; Rho et al., 2005).

Medicinal plants, including Centella asiatica Linn. (C. asiatica), are natural sources of bioactive compounds that possess health-promoting effects. $C$. asiatica has been used to treat a range of ailments, including the common cold (Roy et al., 2013). In Thailand, its fresh leaves have been used to treat wounds and burns and its extract has been used to reduce swelling and infection. C. asiatica extract is widely available in Thailand and cost effective (Taemchuay et al., 2009). Many scientific studies have researched traditional applications of C. asiatica extract (Bylka et al., 2014; Hashim, 2014). C. asiatica extract contains several bioactive compounds, including saponins, essential oils, flavone derivatives, sesquiterpenes, triterpenic acid, and triterpenic steroids (Roy et al., 2013). It also has been reported to contain bioactive compounds, such as terpenes, flavonoids, and polyphenols, that are related to its potent antioxidative activities (Hashim et al., 2011; Nurlaily et al., 2012; Orhan et al., 2013). Extracts from $C$. asiatica leaves consist of gallic acid and ferulic acid, which have antioxidant and anti-inflammatory effects (Ramesh et al., 2014). Another study has shown that $C$. asiatica extracts exhibited antioxidant activity and UV protection effects (Hashim et al., 2011). Many beauty products are currently available that incorporate $C$. asiatica extracts, such as cosmetic creams, hand and body lotions, eye gel, and face mask products (Bylka et al., 2014). A previous study found that $C$. asiatica extract enlarged hair follicles (Jain and Dass, 2015) and inhibited the activity of $5 \alpha$-reductase that causes hair loss (Jain et al., 2016). However, few hair care or restoration products contain the extract, as its effect on the hair root remains unclear; the molecular mechanisms involved in plant extracts modulating gene expression are not well understood.

The in vitro treatment of human follicle dermal papilla cells could, possibly, provide a gateway to hair regeneration and sustainably protect against hair loss. The objective of this study was to search for any potential effect, especially involving antioxidant activity, of $C$. asiatica extract on growth and molecular regulation in human follicle dermal papilla cells. Positive findings would indicate the potential for developing accessible and affordable value added hair growth promoting products using ingredients extracted from natural sources rather than synthetic drugs. 


\section{MATERIALS AND METHODS}

\section{Plant material}

A C. asiatica plant was collected from Chiang Rai, Thailand and positively identified by the taxonomist of Nareasuan University. The leaves were cleaned and dried in an oven at $40^{\circ} \mathrm{C}$, then stored at $-20^{\circ} \mathrm{C}$ until use.

\section{Preparing the ethanol crude extract}

One kilogram of dried samples were ground into powder and macerated in $4 \mathrm{~L}$ of $70 \%$ $(\mathrm{v} / \mathrm{v})$ ethanol $(\mathrm{EtOH})$ for $24 \mathrm{~h}$ at room temperature. The extraction was performed twice under the same conditions. Chlorophyll was removed using the charcoal absorption method with some modification (Limtrakul et al., 2004). Briefly, each extract was bleached with $160 \mathrm{~g}$ of activated charcoal. The chlorophyll-free extract was then filtered through Whatman's No.1 filter paper and the solvent was removed using a vacuum rotary evaporator (Buchi, Switzerland) at room temperature. The concentrated aqueous portion was lyophilized (Christ Alpha1-4 LD, UK) into a powder and further partitioned using four different solvents: hexane, dichloromethane $\left(\mathrm{CH}_{2} \mathrm{Cl}_{2}\right)$, ethyl acetate $(\mathrm{EtOAc})$, and water $\left(\mathrm{H}_{2} \mathrm{O}\right)$. The EtOH crude extract and four fractions with the highest antioxidant activity were then used in subsequent experiments.

\section{Evaluating the free radical scavenging activity of the crude extract}

Two methods measured the free radical scavenging activity of $C$. asiatica crude extract: 1) a DPPH inhibition assay following the method of Padmanabhan and Jangle (2012) and 2) an ABTS inhibition assay as described by Gorjanović et al. (2012). With treatments of various concentrations of the extract, the decrease in absorbance was measured at $517 \mathrm{~nm}$ for the DPPH assay and $735 \mathrm{~nm}$ for the ABTS assay; the \% inhibition and $\mathrm{IC}_{50}$ value were also reported.

\section{Measuring total phenolic and flavonoid contents of the crude extract}

Total phenolic content was determined using the Folin-Ciocalteu method. Quantification was expressed as milligrams of gallic acid equivalent per gram of extract (mg GE/g of ext) (Saikia et al., 2012). The total flavonoid content (TF) was measured by aluminium chloride colorimetric assay and expressed in milligrams of catechin equivalent per gram of extract (mg CE/g of ext) (Saikia et al., 2012).

\section{Human follicle dermal papilla cell cultures and cell viability testing}

Human follicle dermal papilla cells cultures were obtained from PromoCell, Germany. The cells were cultured and maintained in Follicle Dermal Papilla Cell Growth Medium (PromoCell, Germany) at $37^{\circ} \mathrm{C}$ in $5 \%(\mathrm{v} / \mathrm{v}) \mathrm{CO}_{2}$. Cytotoxicity of the extract of the human follicle dermal papilla cells was performed using the Presto-blue (Invitrogen, USA) assay according to the PrestoBlue ${ }^{\mathrm{TM}}$ cell viability reagent protocol. Briefly, $2 \times 10^{3}$ of the human follicle dermal papilla cells were seeded into a 96-well, flat-bottomed, microliter plate and cultured for $24 \mathrm{~h}$. A $100-\mu \mathrm{l}$ sample of $C$. asiatica extract at different concentrations was 
added to each well and the cells were further cultured for $24 \mathrm{~h}$ for one group of cells, and $48 \mathrm{~h}$ for another. Then, $20 \mu \mathrm{l}$ of Presto-blue solution was added to each well and the cells were incubated for $20 \mathrm{~min}$. The $C$. asiatica extracts were compared to $1 \%$ standard minoxidil (Sigma-Aldrich, USA) as the control. The absorbance was measured at $570 \mathrm{~nm}$. The effective time of incubation to human follicle dermal papilla cells was used for studying the mRNA expression.

\section{Detecting VEGF mRNA expression in $C$. asiatica-treated human follicle dermal papilla cells}

The human follicle dermal papilla cells were treated with the indicated concentrations of C. asiatica extract for $24 \mathrm{~h}$. Total RNA was isolated using RNAZol ${ }^{\circledR}$ RT (Molecular Research Center Inc., USA) according to the manufacturer's protocol. RNA quality was assessed by RNA/Protein sample PCR amplification of cDNA performed in a RevertraAce ${ }^{\circledR}$ qPCR RT Master Mix (Toyobo, Japan). cDNA was obtained from $2 \mu \mathrm{g} / \mathrm{ml}$ of RNA by one cycle of reverse transcription. Gene expression was quantified using real-time PCR (RT-PCR). Targeted genes and the details are presented in Table 1 . The PCR cycle steps consisted of denaturation at $94^{\circ} \mathrm{C}$ for $1 \mathrm{~min}$, annealing at $58^{\circ} \mathrm{C}$ for $1 \mathrm{~min}$, and a final extension step at $72^{\circ} \mathrm{C}$ for $1 \mathrm{~min}$ within 40 cycles. Each gene expression was calculated according to the threshold cycle $\left(\mathrm{C}^{\mathrm{T}}\right)$ value, normalized using the value of sample with the lowest level for each product, and the data were corrected according to the level of $\beta$-actin.

Table 1. Sequences of gene specific primers used in RT-PCR.

\begin{tabular}{|c|c|c|c|}
\hline Genes & Sequences & Size & Reference \\
\hline \multirow[t]{2}{*}{ VEGF } & forward 5' - ATGACGAGGGCCTGGAGTGTG -3' & \multirow[t]{2}{*}{91} & \multirow{2}{*}{$\begin{array}{l}\text { Soulitzis et al., } \\
2006\end{array}$} \\
\hline & reverse 5'-CCTATGTGCTGGCCTTGGTGAG -3' & & \\
\hline \multirow[t]{2}{*}{$\beta$-actin } & forward, 5'- CTTCCAGCCTTCCTTCCTGG -3' & \multirow[t]{2}{*}{162} & \multirow{2}{*}{$\begin{array}{l}\text { Soulitzis et al., } \\
2006\end{array}$} \\
\hline & reverse, 5'- TTCTGCATCCTGTCGGCAAT -3' & & \\
\hline
\end{tabular}

To verify the RT-PCR, PCR products were analyzed by electrophoresis in $2 \%$ agarose gels. They were then stained with ethidium bromide and photographed on a UV light transilluminator. PCR product length for VEGF growth factor was analyzed, as well as $\beta$-actin.

\section{Statistical analysis}

Each experiment was performed in triplicate. All values were presented as a mean value (Mean $\pm \mathrm{SD}$ ). The statistically significant differences between the means of the samples were calculated by one-way ANOVA and the differences were considered significant at a level of $p<0.05(*)$. 


\section{RESULTS}

\section{Antioxidant activity of $C$. asiatica extracts}

The antioxidant activity of the $C$. asiatica extract was measured by its ability to scavenge DPPH and ABTS radicals.

Figure 1 shows the DPPH (A) and ABTS (B) free radical scavenging assays. The free radical scavenging activity of $C$. asiatica extract showed the highest activity in the EtOH crude extract for DPPH assay and the highest activity in the EtOAc fraction for ABTS assay.
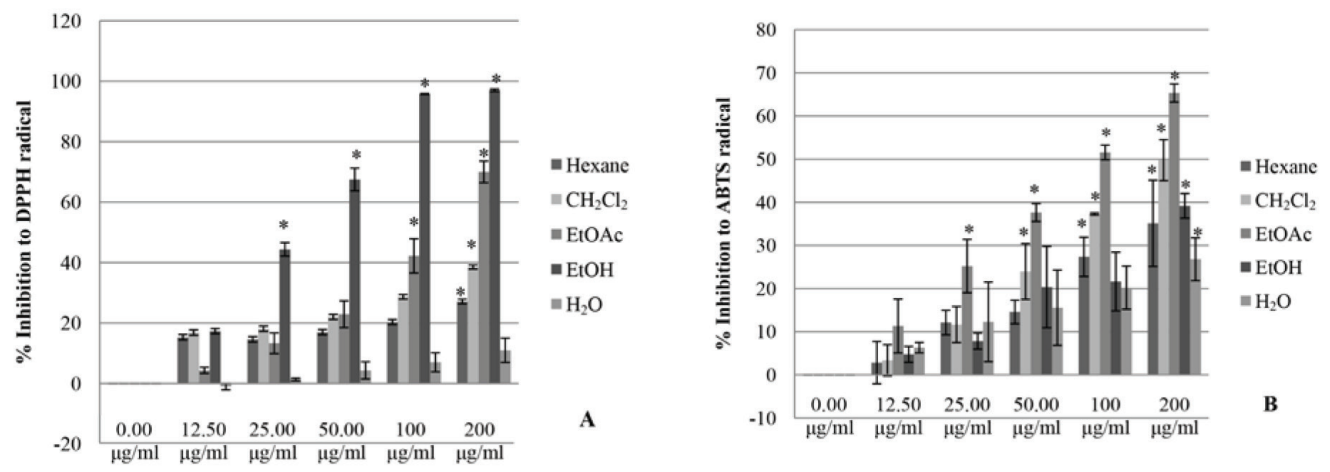

Figure 1. The free radical scavenging activities of $C$. asiatica extracts.

Note: *The differences were considered significant at $p<0.05$.

Table 2. $\mathrm{IC}_{50}$ of the $C$. asiatica extracts against $\mathrm{DPPH}$ and ABTS radicals.

\section{Fraction}

$\mathrm{IC}_{50}$ of $C$. asiatica extract $(\mu \mathrm{g} / \mathrm{ml})$

\begin{tabular}{lcc} 
& DPPH assay & ABTS assay \\
\hline Hexane & $>200$ & $>200$ \\
$\mathrm{CH}_{2} \mathrm{Cl}_{2}$ & $>200$ & $173.20 \pm 3.47$ \\
$\mathrm{EtOAc}$ & $134.76 \pm 12.09$ & $122.22 \pm 7.49$ \\
$\mathrm{EtOH}$ & $34.63 \pm 0.76$ & $>200$ \\
$\mathrm{H}_{2} \mathrm{O}$ & $>200$ & $>200$ \\
Ascorbic acid & $13.95 \pm 0.01$ & - \\
Trolox & - & $6.41 \pm 0.03$ \\
\hline
\end{tabular}

Note: The presence of $\mathrm{IC}_{50}$ of $C$. asiatica and standards against DPPH and ABTS radicals are presented as mean $\pm \mathrm{SD}$. 
As shown in Figure 1 and Table 2, the free radical scavenging activity of $C$. asiatica extract at $0-200 \mu \mathrm{g} / \mathrm{ml}$ was found to scavenge the DPPH radicals and ABTS radicals in a dose dependent manner when compared with the positive control, ascorbic acid and Trolox.

The EtOH crude extract of $C$. asiatica at a concentration of $200 \mu \mathrm{g} / \mathrm{ml}$ displayed the highest inhibitory effect; it inhibited DPPH radicals at $97.01 \pm 0.42 \%$ of the ascorbic acid and also inhibited $\mathrm{IC}_{50}$ at $34.63 \pm 0.76 \mu \mathrm{g} / \mathrm{ml} . \mathrm{CH}_{2} \mathrm{Cl}_{2}$, hexane, and $\mathrm{H}_{2} \mathrm{O}$ fractions also displayed inhibitory effects at the same concentration levels of $\mathrm{IC}_{50}(>200 \mathrm{ug} / \mathrm{ml})$.

C. asiatica extract in the EtOAc fraction displayed the highest inhibitory effect on ABTS radicals at a concentration of $200 \mu \mathrm{g} / \mathrm{ml}$, inhibiting $65.33 \pm 2.09 \%$ of Trolox with $\mathrm{IC}_{50}$ at $122.22 \pm 7.49 \mu \mathrm{g} / \mathrm{ml}$. The $\mathrm{CH}_{2} \mathrm{Cl}_{2}$ fraction inhibited at $\mathrm{IC}_{50}$ of $173.20 \pm 3.47 \mu \mathrm{g} / \mathrm{ml}$. EtOH crude extract, hexane fraction, and $\mathrm{H}_{2} \mathrm{O}$ fraction had the same concentration levels $(>200 \mathrm{ug} / \mathrm{ml})$.

The two active fractions, the EtOH crude extract and EtOAc fraction, have been linked to solvent polarity that can extract different fractions of polar/nonpolar constituents from the plant. This finding agreed well with the total phenolic and flavonoid contents of each fraction, as shown in Table 3.

\section{Total phenolic and flavonoid content in $C$. asiatica extracts}

The amount of phenols and flavonoids contained in $C$. asiatica extracts are shown in Table 3. The EtOAc fraction contained the most phenolic compounds, at $19.72 \pm 0.02 \mathrm{mg}$ $\mathrm{GE} / \mathrm{g}$ of extract, closely followed by the $\mathrm{CH}_{2} \mathrm{Cl}_{2}$ fraction. The EtOAc fraction contained the most flavonoids, at $6.79 \pm 0.12 \mathrm{mg} \mathrm{CE} / \mathrm{g}$ of extract, with all other fractions containing only small or trace amounts.

Table 3. Total phenolic (TP) and flavonoid (TF) content of $C$. asiatica extracts.

\begin{tabular}{cccccc}
\hline C. asiatica & Hexane & $\mathbf{C H}_{2} \mathbf{C l}_{2}$ & EtOAc & EtOH & $\mathbf{H}_{2} \mathbf{O}$ \\
\hline TP (mg GE/g of ext) & $7.71 \pm 0.01$ & $17.04 \pm 0.01$ & $19.72 \pm 0.02$ & $2.68 \pm 0.00$ & $0.13 \pm 0.00$ \\
TF (mg CE/g of ext) & $1.10 \pm 0.64$ & $1.51 \pm 0.36$ & $6.79 \pm 0.12$ & $0.54 \pm 0.14$ & $0.00 \pm 0.00$ \\
\hline
\end{tabular}

Note: The present chemical components, including TP and TF, are presented as mean $\pm \mathrm{SD}$.

\section{Cytotoxicity of the $C$. asiatica extracts}

The cytotoxicity of the $C$. asiatica extract from $\mathrm{EtOH}$ crude extract and each fraction were further examined by treating human follicle dermal papilla cells with the extract at different concentrations. The EtOH crude extract and $\mathrm{H}_{2} \mathrm{O}$ fraction were evaluated for cytotoxic effects on human follicle dermal papilla cells at different doses up to $1,000 \mu \mathrm{g} / \mathrm{ml}$ extract for $24 \mathrm{~h}$ and $48 \mathrm{~h}$ (Figure 2). The cell viability was $100 \%$ or more compared with the non-treated cells $(0 \mu \mathrm{g} / \mathrm{ml}$ extract). The $C$. asiatica extract at concentrations of $500 \mu \mathrm{g} / \mathrm{ml}$ and $1,000 \mu \mathrm{g} / \mathrm{ml}$ slightly induced cell proliferation. From this, it can be concluded that the EtOH crude extract and $\mathrm{H}_{2} \mathrm{O}$ fraction of $C$. asiatica did not show any toxicity to the human follicle dermal papilla cells, and in this regard were as effective as $1 \mu \mathrm{g}$ of minoxidil (control). No statistical differences were found between the viability of the cells treated with minoxidil, 
and the viability of the cells in the control. Unfortunately, the screening data revealed that the EtOAc fraction, which possessed the greatest antioxidant activity, was toxic to human follicle dermal papilla cells (data not show). Therefore, we did not use this fraction for further study. We then focused on the extract from the safer solvents - EtOH and $\mathrm{H}_{2} \mathrm{O}$.

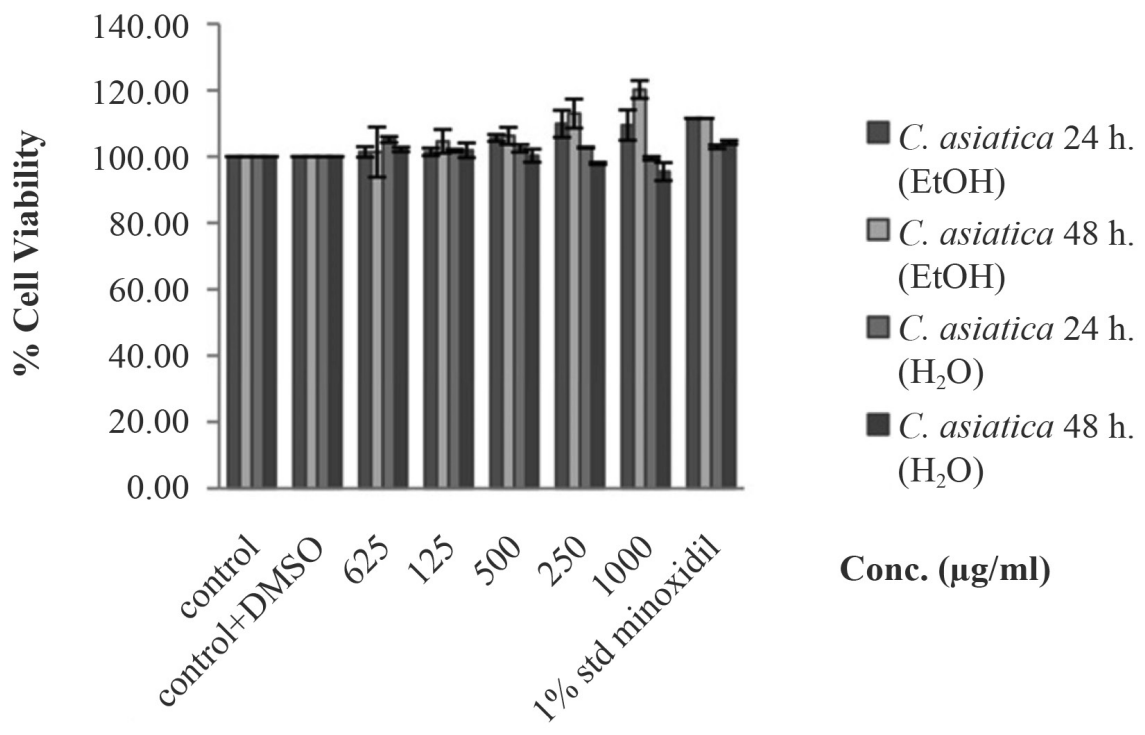

Figure 2. Cell viability of EtOH crude extract and $\mathrm{H}_{2} \mathrm{O}$ fraction of $C$. asiatica extract at $24 \mathrm{~h}$ and $48 \mathrm{~h}$. The EtOH crude extract and $\mathrm{H}_{2} \mathrm{O}$ fraction did not display cytotoxicity to human follicle dermal papilla cells.

Note: *The differences were considered significant at $p<0.05$.

\section{VEGF gene expression}

The EtOH crude extract and $\mathrm{H}_{2} \mathrm{O}$ fraction (the safer solvents) of $C$. asiatica at concentrations of $500 \mu \mathrm{g} / \mathrm{ml}$ and $1,000 \mu \mathrm{g} / \mathrm{ml}$ were used for a gene expressivity assay by RTPCR. As shown in Figure 3, both concentrations of EtOH crude extracts of C. asiatica induced VEGF gene expression $(p<0.05)$, with $500 \mu \mathrm{g} / \mathrm{ml}$ the most at $37.30 \pm 9.47$. This far exceeded the slightly induced VEGF gene expression of minoxidil $(1.99 \pm 0.07)$; the $\mathrm{H}_{2} \mathrm{O}$ fraction did not induce gene expression (data not shown).

The size of the PCR products corresponded to the data shown in Table 1 . The band of VEGF growth factor was presented after incubating the $C$. asiatica extract with human follicle dermal papilla cells. C. asiatica extract at the concentration of $500 \mu \mathrm{g} / \mathrm{ml}$ showed a more intense band than the $C$. asiatica extract at the concentration $1,000 \mu \mathrm{g} / \mathrm{ml}$. Similarly to the $\beta$-actin, these concentrations showed the same result as VEGF growth factor (data not show). The PCR products coresponded to RT-PCR. 


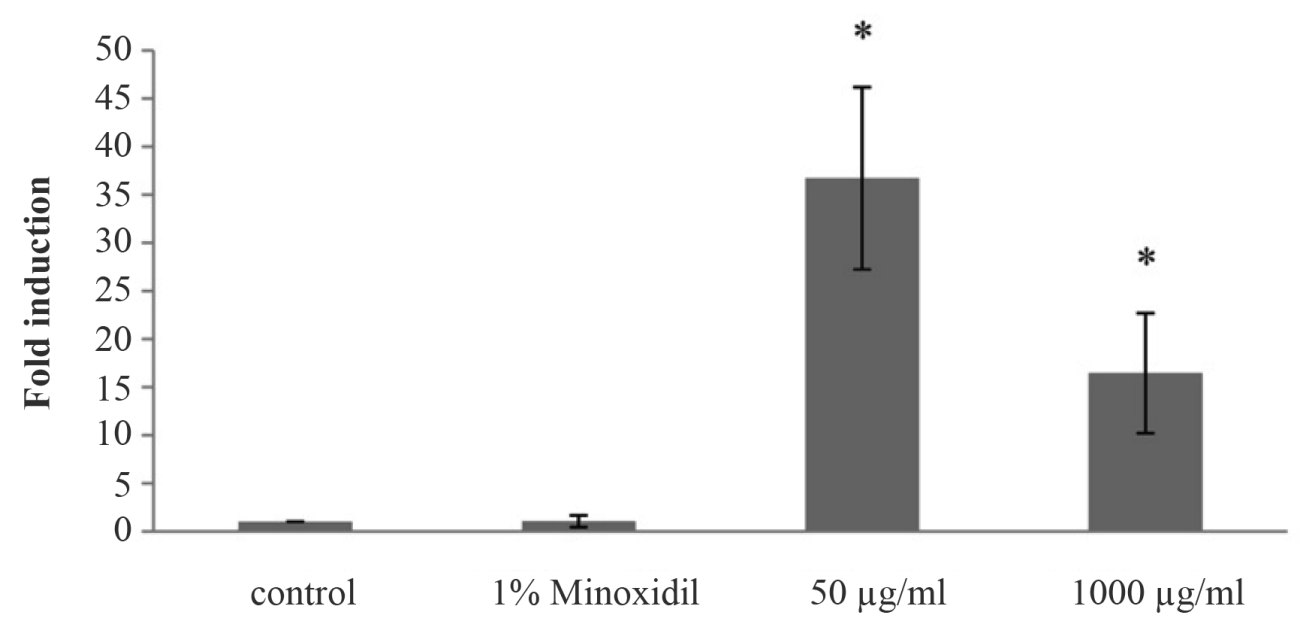

VEGF expression stimulated with $C$. asiatica extract by RT-PCR

Figure 3. VEGF expression of human follicle dermal papilla cells by the induction of EtOH crude extract of $C$. asiatica.

Note: *The differences were considered significant at $p<0.05$.

\section{DISCUSSION}

ABTS and DPPH assays determined the anti-oxidative activity of the $70 \%$-EtOH extract of $C$. asiatica and its partition fractions (hexane, $\mathrm{CH}_{2} \mathrm{Cl}_{2}$, EtOAc, and $\mathrm{H}_{2} \mathrm{O}$ fractions). The different fractions inhibited the ABTS and DPPH radicals differently. The EtOH crude extract showed the strongest inhibitory effect on DPPH radicals, while the EtOAc fraction had the strongest inhibitory effect on the ABTS radicals. These results indicated that the free radical scavenging activities correlated to the phenolic and flavonoid content in the extract. Moreover, the inhibitory effect of both the EtOH crude extract and the EtOAc fraction depended on not only their phytochemical ingredients, but also the solvents used to generate the radicals. Water was used as the solvent in the ABTS assay, representing the polar solvent borne radicals (Gorjanović et al., 2012), while methanol used as the solvent in the DPPH assay, representing the organic solvent borne radicals (Padmanabhan and Jangle, 2012). Rahman et al. (2013) and Shalaby and Shanab (2013) found that the free radical scavenging activity of an extract related to the polarity of the solvent, which occurs because the antioxidant molecules engage in strong interactions with free radicals.

The results showed that the free radical scavenging activity of the $C$. asiatica extracts related to the variety of chemicals in the phenols and flavonoids, which included many lipophilic phytochemicals or hydrophilic phytochemicals. Many studies have reported levels and activities of phenols and flavonoids using a chlorophyll-free extraction method (Limtrakul et al., 2004; Paula et al., 2012). In our study, the $C$. asiatica extracts and fractions showed total phenols ranging from $0.13-19.72 \mathrm{mg} \mathrm{GE} / \mathrm{g}$ of extract. This result agreed with Frederico et al. (2009) for different parts of $C$. asiatica. The flavonoids levels in the C. asiatica extracts were 
high, up to $6.79 \mathrm{mg} \mathrm{CE} / \mathrm{g}$ extract. The EtOAc fraction showed the highest amount of phenols and flavonoids. This was consistent with previous reports that indicated that the moderate polarity of a solvent, such as EtOAc, yields more phenols and flavonoids than other solvents (Wang et al., 2016) and that the polarity of a solvent affects the amount of each (Rahman et al., 2013).

The cytotoxicity tests showed that the EtOAc fraction harmed human follicle dermal papilla cells. Natural glycosides were extracted from the plant by the low polarity of the solvent, causing the harm. Podolak et al. (2010) also described the haemolytic activity and cytotoxicity to cells of these natural glycosides.

RT-PCR analysis tested the stimulating effect of treating cells with EtOH crude extract of $C$. asiatica, observed as the expression of VEGF mRNA. The EtOH crude extract of $C$. asiatica induced VEGF expression in human follicle dermal papilla cells, possibly leading to cell proliferation. Our results agreed with other studies of plant extracts (such as Asiasari radix and Panax ginseng) in enhancing the expression of VEGF (Rho et al., 2005; Shin et al., 2014). Other reports showed that the proliferation of human follicle dermal papilla cells was involved with cytokines signaling (Soma et al., 2003; Rho et al., 2005). $\beta$-catenin causes the signaling of human follicle dermal papilla cell proliferation (Driskell et al., 2011). The $\beta$-catenin activity in the human follicle dermal papilla cells regulates a number of other signaling pathways, including the phosphorelation of downstream signalling, such as the VEGF pathway, that stimulates cell proliferation (Lachgar et al., 1999; Driskell et al., 2011). VEGF also plays an important role in angiogenesis in follicle dermal papilla cells (Yano et al., 2001).

Previously, minoxidil was reported to have a concentration-dependent, biphasic effect on proliferation and differentiation, as well as on growth stimulation in low doses, and to be an anti-proliferative through the expression of cytokines (Kwon et al., 2007). In solution at less than $5 \%$, Minoxidil can safely be applied to the human scalp; this equals a concentration of $1 \mathrm{mM}$ (Han et al., 2004). Our results showed that minoxidil in solution stimulated the expression of VEGF, corresponding to Lachgar et al. (1998) and Li et al. (2001). The higher VEGF expression after treatment with the EtOH crude extract of $C$. asiatica more efficiently promoted human follicle dermal papilla cells than minoxidil.

\section{CONCLUSION}

While many reports have studied $C$. asiatica extracts, few have looked at its effects on human follicle dermal papilla cells and the molecular mechanisms that promote the proliferation of the cells. This study focused on gene expression after incubating the cells with the $C$. asiatica extract. The EtOH crude extract of $C$. asiatica induced the expression of VEGF mRNA in human follicle dermal papilla cells. Moreover, the phenols and flavonoids found in the $C$. asiatica extracts demonstrated antioxidant activity that could maintain the growth of human follicle dermal papilla cells. This study has clearly indicated that the EtOH crude extract of $C$. asiatica will be of benefit in the development of hair care products and hair loss therapy. 


\section{REFERENCES}

Aron, G.N., Paul, T.R., and Bernard, P.N. 2013. Nonsurgical therapy for hair loss. Facial Plastic Surgery Clinics of North America. 21(3): 335-342. https://doi.org/10.1016/j. fsc.2013.04.003

Bressan, R.B., Melo, F.R., Almeida, P.A., Bittencourt, D.A., Visoni, S., Jeremias, T.S., Costa, A.P., Leal, R.B., and Trentin, A.G. 2014. EGF-FGF2 stimulates the proliferation and improves the neuronal commitment of mouse epidermal neural crest stem cells (EPI-NCSCs). Experimental Cell Research. 327(1): 37-47. https://doi.org/10.1016/j. yexcr.2014.05.020

Bylka, W., Znajdek, A.P., Studzinska, S.E., Danczak-Pazdrowska, A., and Brzezinska, M. 2014. Centella asiatica in dermatology: an overview. Phytotherapy Research. 28(8): 1117-1124. https://doi.org/10.1002/ptr.5110

Danilenko, D.M., Ring B.D., and Pierce, G.F. 1996. Growth factors and cytokines in hair follicle development and cycling: recent insights from animal models and the potentials for clinical therapy. Molecular Medecine Today. 2(11): 460-467. https://doi. org/10.1016/1357-4310(96)10045-9

Driskell, R.R., Clavel, C., Michael, R.M., and Watt, F.M. 2011. Hair follicle dermal papilla cells at a glance. Journal of Cell Science. 124(8): 1179-1182. https://doi.org/10.1242/ jcs.082446

Frederico, P., Rafael , C.D., Dalton, D.J., Miriam, T.P.L., and Nadia, R.B. 2009. Antioxidant and cytotoxic activities of Centella asiatica (L) Urb. International Journal of Molecular Sciences. 10: 3713-3721. https://doi.org/10.3390/ijms10093713

Gopu, S., Paul, L.B., and Mei, B.Q. 2015. Fibroblast heterogeneity and its implications for engineering organotypic skin models in vitro. European Journal of Cell Biology. 94(11): 483-512. https://doi.org/10.1016/j.ejcb.2015.08.001

Gorjanović, S., Komes, D., Pastor, F.T., Belščak-Cvitanović, A., Pezo, L., Hečimović, I., and Suznjevic, D. 2012. Antioxidant capacity of teas and herbal infusions: polarographic assessment. Journal of Agricultural and Food Chemistry. 60(38): 9573-9580. https:// doi.org/10.1021/jf302375t

Han, J.H., Kwon, O.H., Chung, J.H., Cho, K.H., Eun, H.C., and Kim, K.H. 2004. Effect of Minoxidil on proliferation and apoptosis in dermal papilla cell of human hair follicle. Journal of Dermatological Science. 34(2): 91-98. https://doi.org/10.1016/j. jdermsci.2004.01.002

Hashim, P. 2014. The effect of Centella asiatica, vitamins, glycolic acid and their mixtures preparations in stimulating collagen and fibronectin synthesis in cultured human skin fibroblast. Pakistan Journal Pharmaceutical Sciences. 27(2): 233-237.

Hashim, P., Sidek, H., Helan, M.H.M., Sabery, A., Palanisamy, U.D., and Ilham, M. 2011. Triterpene composition and bioactivities of Centella asiatica. Molecules. 16(2): 13101322. https://doi.org/10.3390/molecules 16021310

Hibino, T., and Nishiyama, T. 2004. Role of TGF-beta2 in the human hair cycle. Journal of Dermatological Science. 35(1): 9-18. https://doi.org/10.1016/j.jdermsci.2003.12.003 
Jain, P.K., and Dass, D.J. 2015. Evaluating hair growth potential of some traditional herbs. Asian Journal of Pharmaceutical and Clinical Research. 8(6): 150-152.

Jain, R., Monthakantirat, O., Tengamnuay, P., and De-Eknamkul, W. 2016. Identification of a new plant extract for androgenic alopecia treatment using a non-radioactive human hair dermal papilla cell-based assay. BMC Complementary and Alternative Medicine. 16(18): 1-9. https://doi.org/10.1186/s12906-016-1004-5

Kang, B.M., Won, G.H., Jang, Y.J., Shin, S.H., Kwack, M.H., Choi, S.S., Kim, M.K., Kim, J.C., and Sung, Y.K. 2013. Erythropoietin induces insulin-like growth factor-1 from three-dimensional culture of human dermal papilla cells. Journal of Dermatological Science. 69(1): 82-84. https://doi.org/10.1016/j.jdermsci.2012.10.005

Kwon, O.S., Han, J.H., Yoo, H.G., Chung, J.H., Cho, K.H., Eun, H.C., and Kim, K.H. 2007. Human hair growth enhancement in vitroby green tea epigallocatechin-3-gallate(EGCG). Phytomedicine. 14(7-8): 551-555. https://doi.org/10.1016/j.phymed.2006.09.009

Lachgar, S., Charveron, M., Gall, Y., Plouet, J., and Bonafe, J.L. 1998. Minoxidil upregulates the expression of vascular endothelial growth factor in human hair dermal papilla cells. British Journal of Dermatology. 138(3): 407-411. https://doi.org/10.1046/j.13652133.1998.02115.x

Lachgar, S., Charveron, M., Sarraute, J., Mourard, M., Gall, Y., and Bonafe, J.L. 1999. In vitro main pathways of steroid action in cultured hair follicle cells: vascular approach. Journal of Investigative Dermatology Symposium Proceeding, 4(3), 290-295.

Li, W., Man, X.Y., Li, C.M., Chen, J.Q., Zhou, J., Cai, S.Q., Lu, Z.F., and Zheng, M. 2012. VEGF induces proliferation of human hair follicle dermal papilla cells through VEGFR-2-mediated activation of ERK. Experimental Cell Research. 318(14): 16331640. https://doi.org/10.1016/j.yexcr.2012.05.003

Li, M., Marubayashi, A., Nakaya, Y., Fukui, K., and Arase, S. 2001. Minoxidil-induced hair growth is mediated by adenosine in cultured dermal papilla cells: possible involvement of sulfonylurea receptor $2 \mathrm{~B}$ as a target of minoxidil. Journal of Investigative Dermatology. 117(6): 1594-1600. https://doi.org/10.1046/j.0022-202x.2001.01570.x

Limtrakul, P., Khantamat, O., and Pintha, K. 2004. Inhibition of P-glycoprotein activity and reversal of cancer multidrug resistance by Momordica charantia extract. Cancer Chemotherapy and Pharmacology. 54: 525-530. https://doi.org/10.1007/s00280-0040848-4

Nurlaily, A., Noor Baitee, A. R. and Musalmah, M. 2012. Comparative antioxidant and antiinflammatory activity of different extracts of Centella asiatica (L.) Urban and its active compounds, Asiaticoside and Madecassoside. Medicine and Health. 7(2): 62-72.

Orhan, I.E., Atasu, E., Senol, F.S., Ozturk, N., Demirci, B., Das, K., and Sekeroglu, N. 2013. Comparative studies on Turkish and Indian Centella asiatica (L.) Urban (gotu kola) samples for their enzyme inhibitory and antioxidant effects and phytochemical characterization. Industrial Crops and Products. 47: 316-322. https://doi.org/10.1016/j. indcrop.2013.03.022

Padmanabhan, P., and Jangle, S.N. 2012. Evaluation of DPPH radical scavenging activity and reducing power of four selected medicinal plants and their combinations. International Journal of Pharmaceutical Science and Drug Research. 4(2): 143-146. 
Panchaprateep, R., and Asawanonda, P. 2014. Insulin-like growth factor-1: roles in androgenetic alopecia. Experimental Dermatology. 23(3): 216-218. https://doi. org/10.1111/exd.12339

Park, P.J., Moon, B.S., Lee, S.H., Kim, S.N., Kim, A.R., Kim, H.J., Park, W.S., Choi, K.Y., Cho, E.G., and Lee, T.R. 2012. Hair growth-promoting effect of Aconiti Ciliare Tuber extract mediated by the activation of Wnt/ $\beta$-catenin signaling. Life Sciences. 91(1920): 935-943. https://doi.org/10.1016/j.lfs.2012.09.008

Paula, C.C., Sonia, S.F., Tatiana, S.W., and Sandra, C.G. 2012. Evaluation of the antimicrobial and antioxidant activities of essential oils, extracts and their main components from oregano from Madeira Island, Portugal. Food Control. 23(2): 552-558. https://doi. org/10.1016/j.foodcont.2011.08.031

Podalak, I., Galanty, A., and Sobolewska, D. 2010. Saponins as cytotoxic agents: a review. Phytochemisty Reviews. 9: 425-474. https://doi.org/10.1007/s11101-010-9183-Z

Rahman, M., Hossain, S., Rahaman, A., Fatima, N., Nahar, T., Uddin, B., and Basunia, M.A. 2013. Antioxidant activity of Centella Asiatica (Linn.) Urban: impact of extraction solvent polarity. Journal of Pharmacognosy and Phytochemistry. 1(6): 27-32.

Rahmani, W., Abbasi, S., Hagner, A., Raharjo, E., Kumar, R., Hotta, A., Magness, S., Metzger, D., and Biemaskie, J. 2014. Hair follicle dermal stem cells regenerate the dermal sheath, repopulate the dermal papilla, and modulate hair type. Developmental Cell. 31(5): 543558. https://doi.org/10.1016/j.devcel.2014.10.022

Ramesh, B.N., Girish, T.K., Raghavendra, R.H., Naidu, K.A., Rao, U.J., and Rao, K.S. 2014. Comparative study on anti-oxidant and anti-inflammatory activities of Caesalpinia crista and Centella asiatica leaf extracts. Jornal of Pharmacy and Bioallied Sciences. 6(2): 86-91. https://doi.org/10.4103/0975-7406.129172

Rho, S.S., Park, S.J., Hwang, S.L., Lee, M.H., Kim, C.D., Lee, I.H., Chang, H.Y., and Rang, M.J. 2005. The hair growth promoting effect of Asiasari radix extract and its molecular regulation. Journal of Dermatological Science. 38(2): 89-97. https://doi.org/10.1016/j. jdermsci.2004.12.025

Roy, D.C., Barman, S.K., and Shaik, M.M. 2013. Current updates on Centella asiatica: phytochemistry, pharmacology and traditional uses. Medicinal Plant Research. 3(4): 20-36. https://doi.org/10.5376/mpr.2013.03.0004

Saikia, S., Dutta, H., Saikia, D., and Mahanta, C.L. 2012. Quality characterization and estimation of phytochemical content and antioxidant capacity of aromatic pigmented and non-pigmented rice varieties. Food Research International. 46(1): 334-340. https:// doi.org/10.1016/j.foodres.2011.12.021

Shalaby, E.A., and Shanab, S.M.M. 2013. Comparision of DPPH and ABTS assays for determining antioxidant potential of water and methanol extracts of Spirulina platensis. Indian Journal of Geo-Marine Sciences. 42(5): 556-564.

Shin, D.H., Cha, Y.J., Yang, K.E., Jang, I.S., Son, C.G., Kim, B.H., and Kim, J.M. 2014. Ginsenoside Rg3 up-regulates the expression of vascular endothelial growth factor in human dermal papilla cells and mouse hair follicles. Phytotherapy Research. 28(7): 1088-1095. https://doi.org/10.1002/ptr.5101 
Soma, T., Dohrmann, C.E., Hibino, T., and Raftery, L.A. 2003. Profile of transforming growth factor-beta responses during the murine hair cycle. Journal of Investigative Dermatology. 121(5): 969-975. https://doi.org/10.1046/j.1523-1747.2003.12516.x

Soulitzis, N., Karyotis, I., Delakas, D., and Spandidos, A. 2006. Expression analysis of peptide growth factors VEGF, FGF2, TGFB1, EGF and IGF1 in prostate cancer and benign prostatic hyperplasia. International Journal of Oncology. 29: 305-314.

Taemchuay, D., Rukkwamsuk, T., Sakpuaram, T., and Ruangwises, N. 2009. Antibacterial activity of crude extracts of centella asiatica against staphylococcus aureus in bovine mastitis. Kasetsart Veterinarians. 19(3): 1-10.

Wang, L., Qiu, P., Long, X.F., Zhang, S., Zeng, Z.G., and Tian, Y.Q. 2016. Comparative analysis of chemical constituents, antimicrobial and antioxidant activities of ethylacetate of Polygonum cuspidatum and its endophytic actinomycete, Streptomyces sp. A0916. Chinese Journal of Natural Medicines. 14(2): 117-123. https://doi.org/10.1016/S18755364(16)60004-3

Yano, K., Brown, L.F., and Detmar, M. 2001. Control of hair growth and follicle size by VEGF-mediated angiogenesis. The Journal of Clinical Investigation. 107(4): 409-417. https://doi.org/10.1172/JCI11317 